Mario Pines, Ph.D.

University of Trieste, Department of Economics, Administrative, Mathematic and Statistic Sciences "Bruno de Finetti" (DEAMS), Trieste, Italy

mario.pines@deams.it

\title{
THE OUTBREAK OF A NEW CONFUSED CENTURY, MONETARY AND FINANCIAL CHAOS, RECONSIDERED
}

Received: October 15, 2018

Accepted: December 25, 2018

Review

\begin{abstract}
The forced overthrow of the historic meter of commercial development, the monetary Gold Standard, as adopted originally in the USA on the first of August 1914 's, triggered, and led during the next decade, the great inflations in France, Germany, Russia and almost all other European Countries. The ensuing convulsions of the social order, the rise of the speculator opportunities, the obliteration of the savings of the laboring and middle classes, based on fixed incomes, produced directly and afterwards, the rise of Bolshevism, Fascism, and Nazism. They were follow-ups of the floating European currencies, perennial budgetary and balance of payments deficits, Central banks' emergency money printing, currency wars and the neo-mercantilism practices.
\end{abstract}

After Nixon 15 August 1971 second American repudiation of the new Gold Exchange Standard, we entered a slow replay of the first experience, trough inflation, large monetary quantitative expansions and, through bursting bubbles, recessions and stagnations and, finally, new consequent barriers and tariffs perspectives. The most relevant comment, I always share in my speeches is this, coming from a statement on the 100th anniversary of the birth of Jacques Rueff. The comment address has been formulated by Lewis E. Lehrman, at the parliament of France (Assemble Nationale), on November 7, 1996: "Money will decide the fate of mankind, because individual liberty is only possible - or even thinkable when confined within the boundaries of a collective discipline, calculated to curb the disorders that uncontrolled action is bound to provoke". (Rueff, 1971).

Keywords: Banks; Other Depository Institutions; Finance; Internal and external deficits; International payments.

JEL: G21 


\section{THE MONETARY DILEMMA: ORIGIN}

Money is very commonly defined as a medium of exchange, a commodity, it is said, is chosen for this purpose, and people who come to market avoid the inconvenience and complication of bartering one product against another. By selling one product against another, for an agreed quantity of the chosen commodity, they use it to buy whatever they might require in future. The chosen commodity has become historically the gold, lately inserted in the, Stop of the Exchequer provision (Horsefield, 1982). The "stop the exchequer" occurred on Tuesday 2 January 1672, just after the Glorious Revolution, also called the Revolution of 1688 (Quinn, 1996), the political overthrown of King James II of England (James VII of Scotland) by a union of English Parliamentarians with the Dutch stadtholder William III, Prince of Orange, who was James's nephew and son-in-law.

The gold standard became a generally accepted measure of value as well as a universally borderless accepted medium of exchange. The repeal of the Corn Laws as a decisive shift toward the free trade in Britain and the opening of a great first trade globalization, that was suddenly and definitely halted by the huge cross orders coming from the World's main markets, asking for price unlimited sales of equities and shares to convert in gold bullions or depositary's titles. The simultaneous orders coming from all continents forced the closure of the NY Stock exchange on the first of August 1914, with the opening of the battle hostilities in the First World War contrary to the previsions of the Morgan committee formulated on Friday afternoon at the Vanderbilt Hotel session.

During the gold standard there were no currency controls or exchange markets turmoil and, asthe transatlantic cable was connected in 1866, the banking and financial crises in New York were quickly transmitted to London or Paris and globally settled. John Monks, the head of the British Trades Union Congress, (he AFL-CIO of Britain), remarked in the agenda for the TUC's Congress in Manchester England, in 1868, listed items needed to be discussed as: "The need to deal with competition from the Asian colonies and the need to match the educational and training standards of the United States and Germany." ${ }^{\mathrm{i}}$

\footnotetext{
iThe first TUC meeting was held in 1868 when the Manchester and Salford Trades Council convened the founding meeting in the Manchester Mechanics' Institute (on what is now Princess Street and was then David Street; the building is at no. 103). The fact that the TUC was formed by Northern Trades Councils was not coincidental. One of the issues, which prompted this initiative, was the perception that the London Trades Council (formed in 1860 and including, because of its location, many of the most prominent union leaders of the day) was taking a dominant role in speaking for the Trade Union Movement as a whole. The second TUC meeting took place in 1869 at the Oddfellows Hall, Temple Street, Birmingham where delegates discussed the eight-hour working day, election of working people to Parliament and the issue of free education.
} 
In those days, people also migrated more than we remember and, other than in wartime, countries did not require passports for travel before 1914. All those immigrants towards America's shores came without visas. When you consider all of globalization before World War I, the world shrank from a size "large" to a size "medium and finally to a set of minimum slices".

The precious metals have been generally chosen by humanity as the most suitable commodity for this purpose aimed to the measure of values and to the protected deferral of the purchasing negotiations. Economists have at times been inclined to teach that this usage is so firmly established that it approximates to a moral principle, if the use a metallic currency were somehow essential to honest dealing. Credit, it is said, is a means of economizing gold and silver. A right and expectative to receive gold serves as well as the gold itself, if all that is required is a reliable medium. So long as gold is required only as a medium of exchange, the right to receive gold fulfils these requirements. It is only when someone acquires the right such as an industrial manufacturer, jewelry dealer, gold leaves or fountain pens trader, who wants to use it as a material for industry, that the physical right would be exercised, and the metal handed over.

The last effort to settle the dispute about currencies is linked to the WW $\mathrm{I}^{\circ}$ and WW II $^{\circ}$ consequences, at Bretton Woods the last argument has become a dispute about gold, after the unsuccessful, unsettled previous Genoa Conference of 1922 based on Hawtrey assumptions (Hawtrey, 1919). Then most of the economists convened on a return to the gold standard, dismissed because of the disrupting huge worldwide general demand. On the first day of August 1914,the sale of equities and the contextual purchase order of gold, with the dollars sale revenues, requeste dall unforeseen, unexpected developments indicating a potential collapse of the New York stocks' exchange and a general wish of gold hoarding for most of the World liquid available assets.

The New Deal in the thirties, after the collapse of both, the plans to return to the gold standard and the confiscation in 1933 of all gold by President Roosevelt, on his assuming the US Presidency, isa linked consequence of the latent barbaric conflict between political messages and real spending possibilities, in their implementation through unconvertible monetary deficits only.

"But a bank can create credit out of nothing. When one bank grants an advance to a trader, two debts are created, one from the trader to the bank, which is payable at a future date, bears interest and is included in the assets of the bank, the other from the bank to the trader, which the trader can assign away by cheque and so use as a means of payment".(Hawtrey,1939).

The large capability of banks to easily create credit and therefore actually inexistent values, after the fractional reserves facility, has strengthened the link 
between banks and political lobbies. Worldwide, since the bank credit has become the principal medium of payment, money, even standard money on legal tender, is no more than a subsidiary medium. We have seen that bank credit can exist without money. That does not means that this is a desirable state of things, but it enables us to understand the proposition that the idea of money is dependent on that of a debt, while that of a debt is not dependent on that of money. After that, the fractional reserves lending capability and the Central Bank clearing and lending facilities arise, with all the monetary and financial imbalances of the last decades.

\section{THE FIRST GLOBALIZATION}

The financial and banking activities unthinkable integration trough commercial banks, especially after the Modernization Act(Gramm-Leach-Bliley Act of 1999) should have always required a clear separation between banks and financial intermediaries, whether they were investing third parties moneys in irregular deposits or house funds.

It will be observed that the working of international monetary systems would be always greatly facilitated if the participating countries had sufficient confidence in one another's currency units, to buy and hold each other currencies as foreign exchange reserves.

The danger of a scarcity of gold or alternative reserves, which was the ground for the recommendation at Genoa in favor of different foreign exchange reserves, is no longer a cause of anxiety. Nevertheless, some use of such reserves had introduced a very desirable element of elasticity through the international gold-exchange standard system proposed by Henry Dexter White at Bretton Woods (Steil, 2013).

In the 1933 Resolution, the new Administration did not insisted on an agreed interpretation of the medium bearing mutual business activity. In case of a difference of opinion, each central bank might choose on its own judgment. That is a thoroughly practical course, because the facts would resolve by themselves all doubts. Anyway, it remains doubtful whether or not there would be a tendency to disequilibrium, calling for corrective action, in any case it probably did not matter very much by then what kind of action would have been taken. When a decided tendency either to depression or to excessive activity, would appear or be revealed, it was hoped that there would no longer linger differences of opinion.

Thus, the plan put forward in 1933 preserved the maximum of freedom and independence for the authorities of that time, a recognition of their individual international task. Is so entirely to the interests of all concerned that should be worth avoiding that any more strict binding agreement would be unnecessary. 
From a trade point of view, the Bretton Woods resolution to enter a general tariffs and trade agreement, worked out a global World Economy growth, likely in the second globalization, as long as the Smith's comparatives advantages worked on a general scale (Smith, 1991).

Ricardo was right; David Ricardo (1772-1823) was the classic English economist who developed the free-trade theory of comparative advantages. Such theory stipulates that, when each nation specialize in the production of goods in which it has a comparative cost structure advantage and then trades with other nations for the goods in which they specialize, there will be an overall gain in trade, and the overall income levels should rise in each trading country. Until the $197115^{\text {th }}$ August panicking declaration of inconvertibility, the pseudo or quasi gold-standard operating as the dollar currency became a legal international tenderable unit of payment, generally accepted and linked to gold on the IMF declared parities (Friedman, 1961). The World experienced a huge increase in its global output, most of the WW 2 damages were restored, at least outside the communist Soviet area.

After some monetary first uncertain evolution, the Smithsonian Institute agreement, the European first monetary union designs, till the EMS definite plan that led to the EURO, the outcome, during the eighties, was a disruptive financial and monetary instability and markets uncertainties' collapsing in the sequence of market bubbles eruptions and general recessions with a general depressed Western economic scenario called austerity (Blyth, 2013).

John Locke was one of England's most famous philosophers. A part of a movement that culminated in the Glorious Revolution of 1688, which disempowered the king and empowered the electorate. Well, people like Lock grounded the notion of what constitutes legitimate rule in individual property rights, without which there can be no economic liberalism, the base of the Deng Xiaoping transformation of China.

Locke had to make several moves: naturalize income and wealth inequality, legitimate the private ownership of land, explain the emergence of labor markets. At base, Locke's liberalism is an economic liberalism, that puts the individual against the state. The present austerity's intellectual history starts here.

Locke, property resides in us a first force in our persons, but it is only important because it is alienable with our labor. That is when I work on something, such as land, our laboring makes it our own. As Locke argued, whatsoever we remove out of state nature and mixed it with our labor, we make it our property.

Luckily, time and habits have given us a device called money that allows us to get over the problem of spoilage. We can store money and swap it for consumables, it 
allows Locke to explain as inevitable, and therefore good, the creation of markets in land, labor, and capital, that happened to be the very political project that people of his class were looking in at that moment. His next step was to protect these new institutions of market from the emergent capitalisms nemesis: the state.

Locke famous right to rebel against and the deep suspicion of the government, only makes sense in relation to the violation of the rights of private property, he has just awarded himself. In Locke's world, the power of the legislature is limited to the public good of the society, which is as freedom from the intervention of government into private especially concerning property, unless citizens consent to it.

Remember that these arguments were formulated in the seventeenth-century England, when public debt was the debt of kings, kings who invoked rights given by God to appropriate the property of others unconditionally. Thus the liberal dilemma that generates austerity is born. The state: wecan't live with it, can't live without it, don't want to pay for it. Laying their intellectual bricks on Locke's narrow foundations are the giants of the Scottish enlightenment, Adam Smith and David Hume.

Turning first to Hume, his contributions to political economy are still of value and explain mot of modern social evolutions. The idea that a monetary stimulus can in the short run stimulate economic activity, but in the end must either show up as inflation or dissipate, without effecting real variables, forms the centerpiece of his essay "On Money." It is also the standard line in contemporary macroeconomic theory where it is known as the long-run neutrality of money thesis. He is also credited with working out the in Richard Contillons (Contillons, 1755)balance-oftrade ideas, through his price-specie-flow mechanism, the mechanism that underlay the nineteenth-century gold standard. We, however, might be interested in Hume for his writings on public credit what we call government debt.

Hume, like Locke, sees money as an instrument, as nothing but representation of labor and commodities, a method of rating or estimating them. Rather, money follows trade, which places Locke's merchant classes, and not the state, at the center of everything. They are, according to Hume, one of the most useful races. For Hume, merchants are the catalyst for trade and the creators of wealth, intermediaries who serve as agents between parts of the State.

If we turn to the actual institutions by which the money of a civilized country is governed, we shall find that the foundation is always a law prescribing by what means a debt may be paid, in technical language, it prescribes what is "legal tender." 
Law never says what may or must be a medium of exchange. Any one is free to use anything as a medium of exchange. The idea of money derives from the idea of a debt. At first, that conclusion may appear to be the pedantry or sophistry. For if the idea of is derived from the idea of a debt, is it not equally true that the idea of a debt is derived from idea of money? Can a debt have any other meaning than an obligation to pay the official money?

So long, as all goes smoothly, it is convenient and legitimate to think of a debt as meaning nothing but an obligation to deliver a specified quantity of gold silver or legal tenderable paper money.

Effectively, the excepting and superficially plausible assumptions seem to break down. Provided the holders of the paper notes were satisfied to carry on circulating them, the assets backing those notes could themselves be illiquid and not suitable for conversion, quickly or reliably, into money. Fromthe practice emerged the system of banking we see emerging and prevailing today. Illiquid assets financed by liquid deposits or banknotes. The interesting feature of free banking was that it revealed the inherent tension between the use of bank liabilities as money, which requires that notes or deposits exchange at face value and the risky nature of current bank assets. If banknotes in the seventeenth century were exchanged at face value, there was a risk that the underlying assets might one day be undated to support that valuation. This alternative view of the history of money has the merit in explaining why bank deposits should comprise the offer a positive rate of return, either explicitly as interest, or, in the case of current accounts, implicitly in the task of subsidized money transmission services.

A basic problem with public debt is that it has no limit, at least until the interest rates on the debt become crushing. Furthermore, debt is easy to play since its costs are hidden and intergenerational, which makes states love debt. Therefore, contemporary, the even more famous Adam Smith was also troubled by the problem of public debt as Hume troubled by the problem of public debt, seeing the slide into insolvency and unreliability as unavoidable. He identifies both the problem and the solution. To solve the problem of debt we should embrace the principle of austerity, otherwise known as the parsimony of the Scots, nowadays the outcome of the trojka.

\section{THE BRETTON WOODS COLLAPSE}

The last political effort to overcome the fiat money threats and worries was overcome in the July 1942 in Bretton Woods. The supremacy of the US undersecretary Henry Dexter White succeed in force an identification of the US dollar to gold bullions as a reserve currency under the gold base equivalence at 35 oz. in a restricted external convertibility to Central banks of Countries adhering to the International Monetary Fund. A quasi gold standard monetary system was 
imposed, with the after war reconstructions programs and IMF and WB facilities as attractive rewards.

Actually, the pseudo gold standard was immediately criticized bay both AngloSaxons and French Authorities and academics. Robert Triffin (Triffin, 1960) and Jacques Rueff were the most critics of the scheme, on the ground of the inconsistency of the huge gold base required to support the likely volume of international imbalances otherwise support by USA fiat money.

Indeed, after the initial phase of the reconstruction, the ideological and military operations of the fifties and sixties, the gap between the physical gold monetary basis locked in Fort Knox and annexed US depositary entities and the dollars widened, and the convertibility was not any more compatible with the huge US dollars balances stationing in the foreign Central banks. It seems strange to assess today's ratio, which shows that the percentage of US dollar is still prevailing in the foreign reserves of Central banks even without the convertibility concession.

These were floating in most of the Central banks and swelling the Eurodollar World market located in the UK. The crisis erupted on 15 August 1971 in the quiet, but not relaxed meeting of Camp David, when President Nixon adopted the temporarily dismantling of the gold standard refusing the conversion request even from Central banks (Mundell, 1999).

Figure 1. Gold Debasement 1971

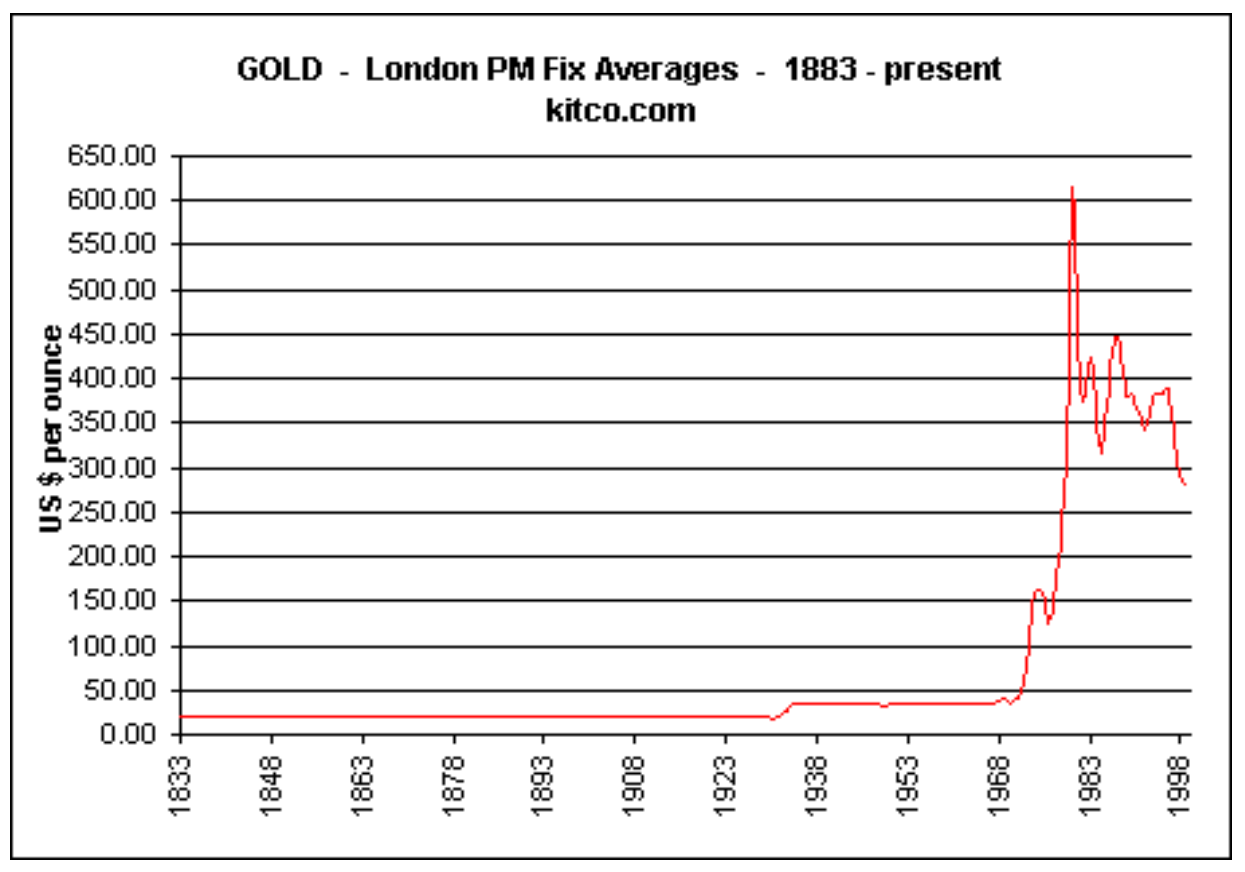


What was then foreseeable did not happen, the price of gold, newly free traded in the markets and released from the monetary basis function started to swell, the dollar lost progressively most of its purchasing power, a decade of inflation wiped away the Phillips curve and its meaning, the new landscape was named stagflation. The WIN (win inflation now) slogan appeared as a pin on American jackets and the economists shifted to the supply side assumption in the economics arenas (Domitrovic, 2018). Arthur Leffer draw his napkin slope, showing the decreasing public revenues, linked to the rising taxation rates and a new monetary era was born.

After the seventies inflationary years and the collapse of the Phillips curve, the eighties saw the major historical changes with the collapse of the Soviet ideology, the Deng reform of the Chinese economy shifted from the, mostly State governance oriented policies, to the market oriented new pattern. A new wave of liquidity spread over the planet but was counterbalanced, in its potential inflationary effects by the reversal of the Asian World plants, left for some decades inactive, now pressing over most of the valuable markets in a competitive unusual competitive costs' structure and unrestricting fiscal hurdles.

The World market since then and in a progressive larger quantity furthermore, was expressing the converging global identical raw materials prices and most of the other production factors. Correspondingly, similar unique costs, with the exception of some specific costs structures, high and growing under some strong compelling forces in the West, are free to float uncontrolled and generally lower in the whole Asian World.

\section{THE MONETARY UNRESOLVED QUESTION}

The main problem facing the modern new Bretton Woods fallout lies on the not extensible legal enforcement of the fiat money principle over the globe, in the inadequacy of a monetary sustainable real basis. The legal enforceable actions are applicable in the single Country issuing his own currency and in the legal local framework, (Simmel, 1898) expressing his philosophical consideration about the objectivity concept of the money value, excludes the international feasibility of a fiat money implementation. He expresses the first potential conflict about two conflicting modern monetary and financial guiding principles: is money a token, a symbol without any value by itself, or we must consider it a value, in order to carry out sound services of measurement, exchange and become substantially a sound saving medium?

Oil was the first surrogate to the gold easily dismissal of 15 August 1971, as long as the oil barrel was available without limits and at convenient prices performing some monetary inappropriate functions even after several Gulf war's fallout of this new evidence. The military North American World police functions were 
supporting the reliability of such function as long as the political division of the World was contraposing the Soviet block to the Western Countries. The introduction of the Euro was a first effort to overcome the unreliable foreign exchange fluctuations within the European Countries, after the demise of the International Monetary Fund balancing power.

In the seventies, and in the eighties, with the appearance of the now powerful far Eastern Countries on the single World market, the demise of the Marxist economies, all exchange rates started to float without a whatsoever safe anchor basis.

The new administration approach, led by F.D. Roosevelt after confiscating in the year 1933 all the physical and title gold, under a penal and monetary relevant fine, was the World safe gold depository owner. At Bretton Woods, the US accepted to a formal constraint to return gold bullions for Central banks adhering to the IMF agreement, on weighted gold reserves based on actual owned gold and floating currencies the gold-exchange system lasted until the demise in Camp David 1971.

As long as the system was running and on short time transitory unbalances, it worked with a soft continuous adjustment with dollar balances and gold deposits shifts providing temporary adjustments.

Figure 2. Compositions of Official Foreign Exchange Reserves Q4 2009

\title{
Currency Compostion of Official Foreign Exchange Reserves, Allocated Reserves (\% of Total, Q4 2009)
}

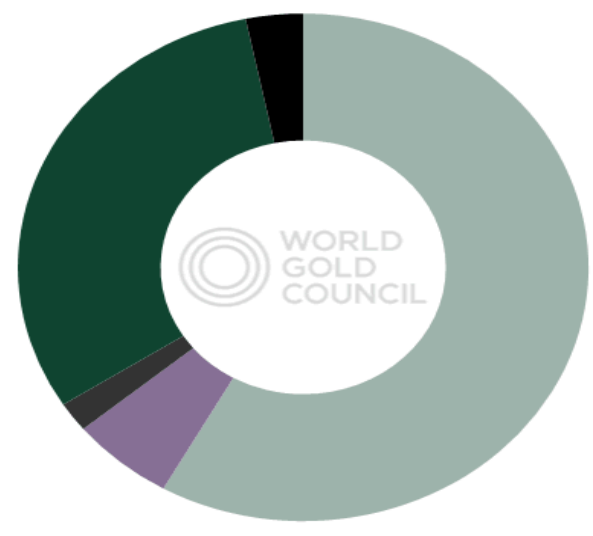

\author{
US dollars $(58.2 \%)$ \\ " Pounds sterling $(5.9 \%)$ \\ - Japanese yen (1.9\%) \\ Euros $(30.8 \%)$ \\ - Others $(3.2 \%)$
}

Source: $<$ http://www.gold.org/government_affairs/reserve_asset_management/> 
Figure 3. Composition of Official Foreign Exchange Reserves Q2 2017

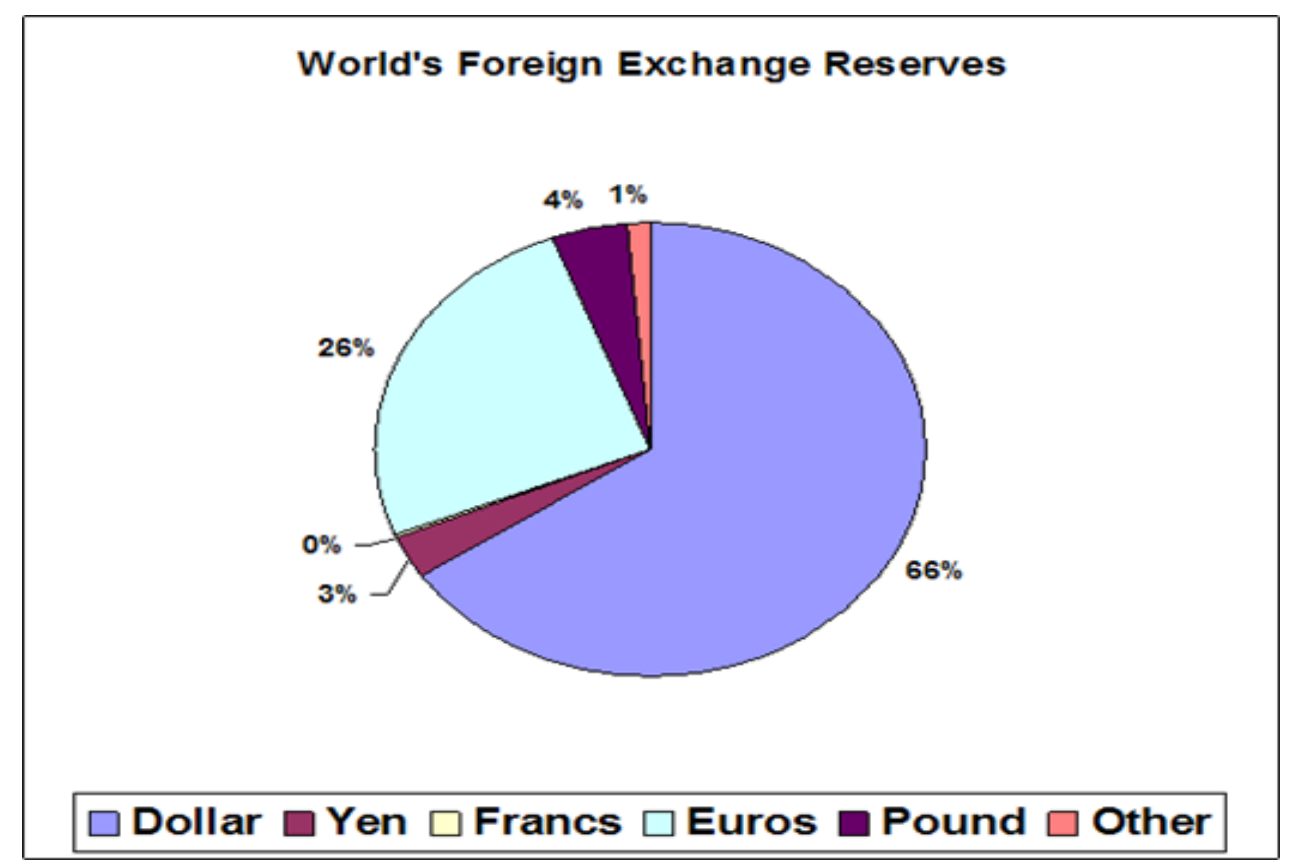

Source: $<$ http://data.imf.org/?sk=E6A5F467-C14B-4AA8-9F6D-5A09EC4E62A4>

The oil price provided successively a progressive balance on a three adjusting factors: oil price, gold reserves and dollars loans, in a gold-oil-exchange international adjusting mechanism.

The present US trade imbalance is disrupting the system since the 1971 Camp David decision, which should have been "temporarily enacted" both the Gold convertibility and the related Bretton Woods agreements, but the international settlement procedures, enacted in the year 1944, are still going on despite a huge US trade deficit, which is progressively growing. The internal deficit, as well, has been disrupting the previous parities, with an over twenty US $\$$ trillion internal debt never seen before as a public deficit. Nevertheless, most likely, the US overpassed the point of no return, as the troubled assets recovery plans and the bailouts have worsened the general American financial scenario (Mallaby, 2016).

Finally, the financial improper commercial banking activities, released through the Modernization, (Gramm-Leach-Bliley Act, 1999) have transformed the classical commercial credit suppliers in social accounting amortizations operating procedures allowing the financial function of the investment banks as inhibited by the Glass and Steagall Act, 1933. 
The final feeling has isolated the US economy in a newly row of old-fashioned tariffs and custom duties, defensive instruments disrupting the efficient trade global system.

\section{CONCLUSION}

The principal beneficiary of this wonderful new international order has been China and some close market economy in the Far East. China has been the principal winner. Back in 1980, China accounted for perhaps 2 percent of the world economy. In addition, the United States and Canada together were about a quarter of the world economy. Today, China accounts for 18 percent of the world economy and the United States and Canada together slightly less than 17 percent. According to the present trends, that differential will grow. By 2021, China will account for a fifth of the world economy. How can there be a reliable international order if the prime beneficiary is a one-party state, run by a communist elite? The challenge has been made to the Western post Colombian economies by the emerging new regions of Eurasia, as described and foreseen by Mc Kinder (Mc Kinder, 1904). We have seen, since then an increasing Islamic extremist disorder, started with the overthrown of Reza Pahlavi, claiming tens of thousands of lives every year since 1979 , the ayatollah Khomeini became the supreme religious leader of the Islamic Republic of Iran. Tens of millions of people displaced from their homes in a growing depression in the rest of the stagnating World have become migrants in search of a better life.

Then, the free-trading system, the so-called General Agreement and Trade, or GATT, had seventy Countries. Twenty-eight countries in 1970. It now, as WTO (World Trade Organization) has 170 members. The European Union (EU), which had six countries in the year 1970, now has twenty-eight - twenty-seven when will be finalized the fall-out of the Great Britain. Still an enormous expansion from that time, the United Nations calculates that in the last fifty years, we have taken more people out of poverty than in the preceding five centuries. 
Figure 4. GDP (US\$ Billions) $2000-2017$

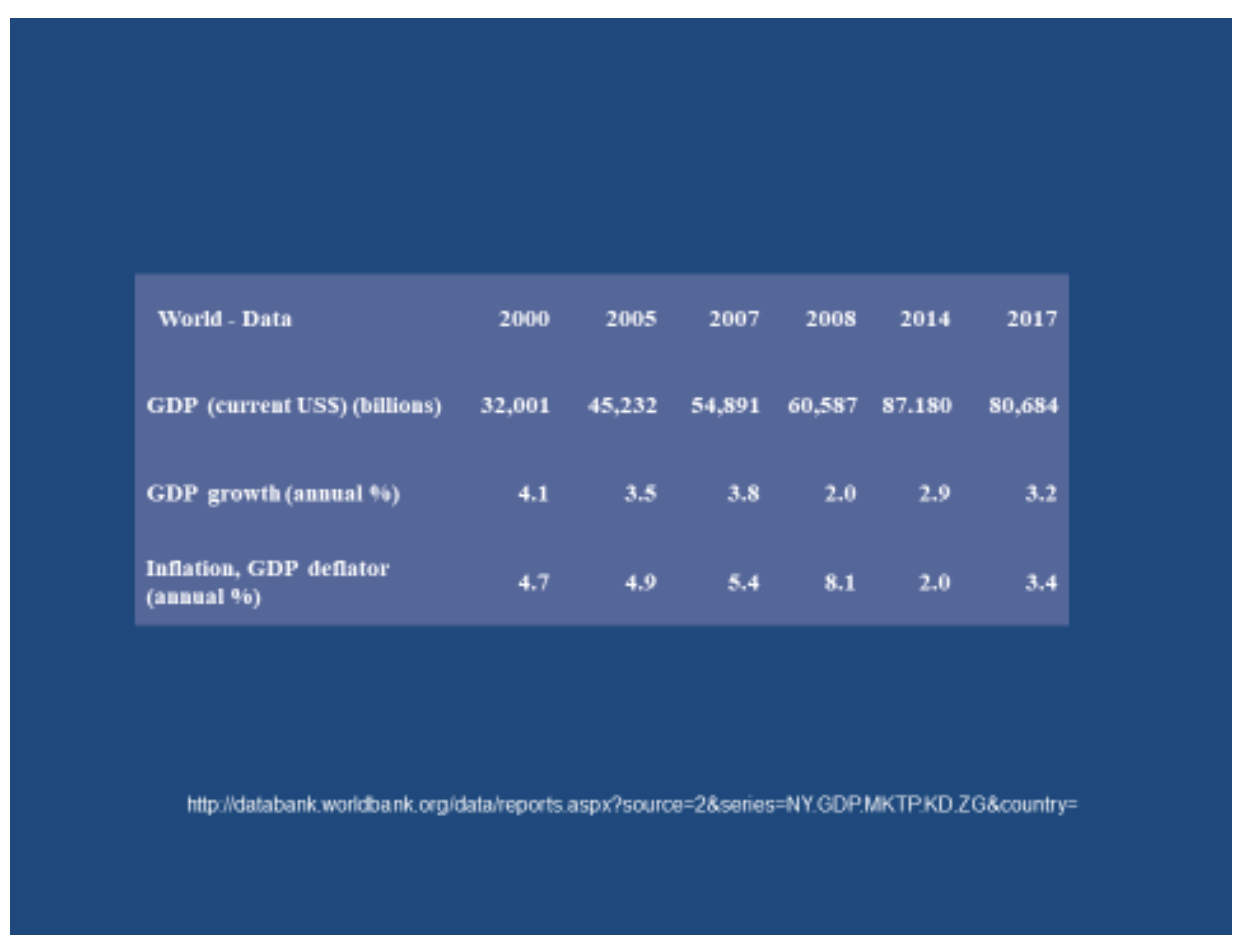

The three stages of the modern banking activity go from the Italian Middle Ages bankers, as outlined in their historical records, to the continental German banks developing the investment banking functions. In their two main sections of prevailing potential institutional activity, they find their modern qualification and definition as monetary functions (Ferguson, 2009). This is the first instance of the conflicting interpretations we encounter about the check: one side contending that the issue of a credit instrument (bank notes or current accounts balance transferrable by checks) merely puts into circulation deposits received beforehand, the other side contending that money comes by such issues. Contillons idea that banknotes are credit instruments, which make a more rapid circulation of money possible, but are not themselves money in the real sense of the word, is completely discarded. Ricardo makes no distinction between the issue of convertible notes and the creation of paper money. He sees precautions concerning those who issue money, and admits that they should be compelled to provide the government with certain guarantees against potential over issues. 
Figure 5. Present external imbalances and austerity factors

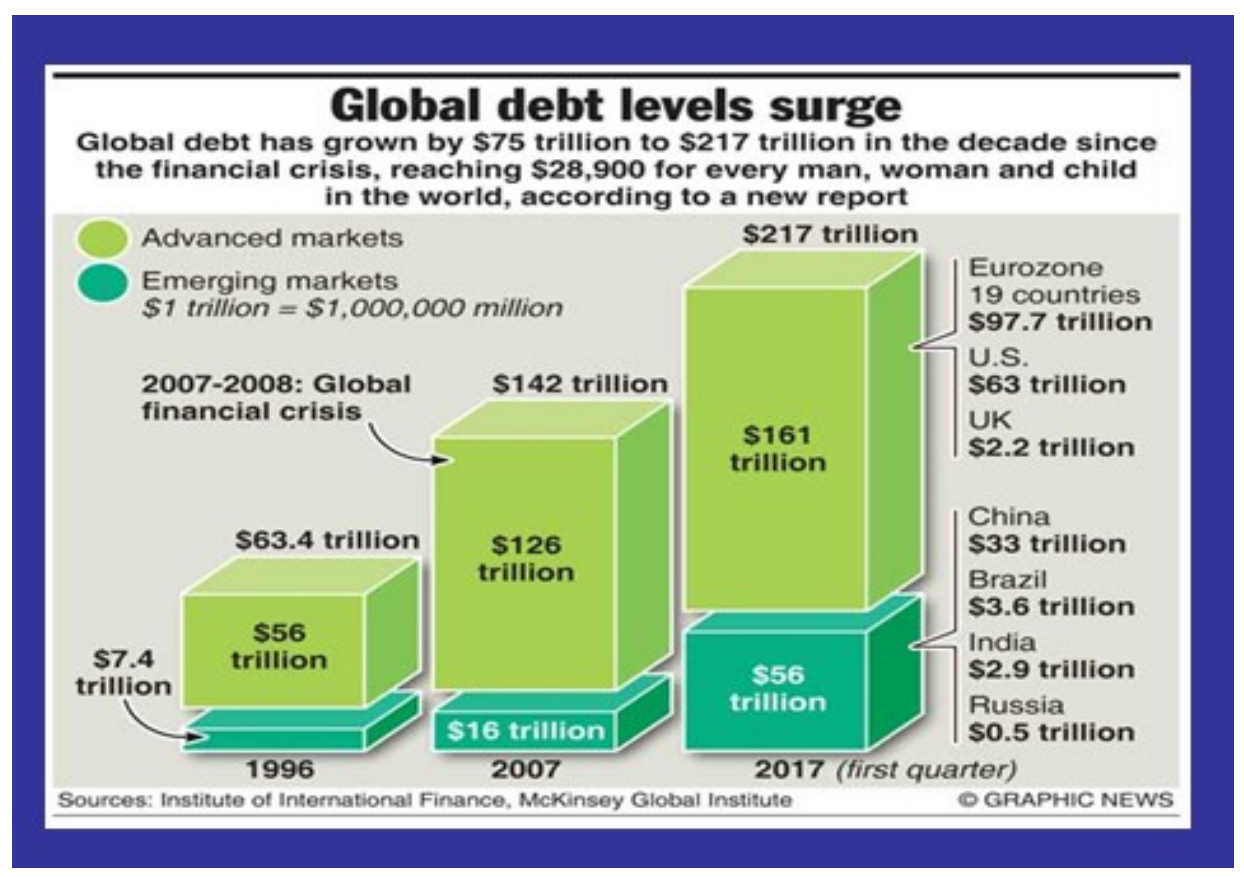

$\mathrm{He}$ is not considering the suggestion that fixed interest bearing securities can serve as sufficient guarantee. Never for a moment does it occur to him that careful selection by the banker in granting credits and responsibility for the convertibility of his notes provide adequate protection for the public. For him there is no difference between money and other circulating media of payment; the only thing that matters is limitation of the quantity.

As to checks, Ricardo thinks of them not as instruments of circulation, but as a means of economizing the use of money. He was the first to make a distinction between checks and banknotes (called to-day bank money and notes) as currency instruments; the eighteenth century had made no such distinction, and it was a long time before the error was eradicated. He came to this conclusion because he did not regard checks as currency instruments; they could not therefore affect prices. This origin of all the debates and discussions led to the passing of the Peel Act in 1844.Under the Act, no bank other than the Bank of England could issue new banknotes, and issuing banks would have to withdraw their existing notes in the event of their being the subject of a takeover. At same time, the Bank of England was restricted to issue new banknotes unless they were $100 \%$ backed by gold or up to $£ 14$ million in government debt. The Act served to restrict the supply of new notes reaching circulation, and gave the Bank of England an effective monopoly on the printing of new notes. The Act exempted demand deposits from the legal 
requirement of a 100 percent reserve, which was demand with respect to the issuance of paper money.

The present century is qualified by a general prevailing of monetary policies of Central banks' policies without normal inflationary following ups (El-Erian, 2016) (DiMartino, 2017) now dismissed (Koo, 2009). At same time, the Asian countries are mostly producing and selling most of their high technology modern production with a single general prevailing advantage, the absence of a strict price control and rigidity in the cost structure and competitive resulting markets prices. In a single 24 hours global market, every industrial factor is strictly monitored and the prices are adjusted to the comparative advantages prices by every single consumer in the World around, correspondingly a global informatics cluster of digital technology networks supply online real time comparative details.

\section{REFERENCES}

1. Blyth, M. (2013), Austerity: The history of a dangerous idea, New York, NY.

2. Contillons, R. (1755), An Essay on Economic Theory, (Translated in English in the year 2010 by the Ludwig von Mises Institute and published under the Creative Commons Attribution License 3.0.) $<$ http://creativecommons.org/licenses/by/3.0/>.

3. DiMartino, B. D. (2017), Fed Up: an insider's take on why the Federal Reserve is bad for America, New York, NY, Barnes \& Noble.

4. Domitrovic, B. (2018), Retrieved from $<\mathrm{http}$ ://www.thegoldstandardnow.org/brian-domitrovic-bio $>$.

5. El-Erian, M. A. (2016), The only game in town: Central banks, instability, and avoiding the next collapse, New York, NY, Random House Audio.

6. Ferguson, N. (2009), The Ascent of Money, London, 285.

7. Friedman, M. (1961), Real and pseudo gold standard,The Journal of Law \& Economics, Vol. 4, 66-79.

8. Hawtrey, R. G. (1919), Currency and credit, London, UK, Longmans.

9. Hawtrey, R. G. (1939), The Gold Standard in Theory \& Practice, Fourth Edition, London.

10. Horsefield, J. K. (1982), The "stop of the exchequer" revisited, The Economic History Review New Series, 35(4), 511-528.

11. Koo, C. R. (2009), The holy grail of macroeconomics: Lessons from Japan's great recession, Singapore, SG, Wiley.

12. Mc Kinder, H. J. (1904), The Geographical Pivot of History, in "The Geographical Journal", Vol. XXIII, n. 4 (April), 421-444.

13. Mallaby, S. (2016), The man who knew, New York, NY, Penguin Press.

14. Mundell, R. (1999), A reconsideration of the twentieth century, retrieved from $<$ http://www.columbia.edu/ ram15/nobelLecture.html $>$.

15. Quinn, S. (1996), Gold, silver, and the Glorious Revolution: arbitrage between bills of exchange and bullion, The Economic History Review, 49, 
473-490. doi:10.1111/j.1468-0289.1996.tb00578.xnce.

16. Rueff, J. (1971), The monetary sin of the west, New York, NY, The Macmillan Company.

17. Simmel, G. (1898), The Philosophy of Money, London, Routledge \& Kegan Paul, NY, 2004.

18. Smith, A. (1991), Wealth of Nations, Library of Congress, New York, NY, 499, ISBN 0-87975-705-1.

19. Steil, B. (2013), The battle of Bretton Woods, Princeton, NJ, Princeton University Press.

20. Triffin, R. (1960), Gold and the dollar crisis: The future of convertibility, New Haven, CT, Yale University Press. 